\title{
"FACE": THE IDENTITY OF THE ISRAELITE COMMUNITY AND THE COMMISSION OF MOSES (EXODUS 33:12-23)
}

\begin{abstract}
Ashok Kujur
ABSTRACT:

Dalam tradisi Perjanjian Lama, frase "wajah Allah" digunakan untuk menggambarkan kehadiran Yahwe, Allah Israel. Artikel ini menganalisis makna kata "wajah" dalam Kel 33:1223 yang berisi dialog antara Musa dengan Yahwe, di mana Musa meminta penyertaan Tuhan di padang gurun. Penulis berusaha menjelaskan kaitan antara kata "wajah" dengan identitas Israel. Untuk menjelaskan kaitan ini, penulis menguraikan terlebih dahulu identitas Musa mengingat pentingnya figur musa dalam formasi iman Israel dalam perjalanan di padang gurun menuju Tanah Terjanji. Bagi penulis, "wajah" menyingkap karakter seseorang dan menyimbolkan diri seseorang. Maka "wajah Yahwe" menjadi begitu penting bagi Musa dan bangsa Israel.
\end{abstract}

Key words:

Moses, exodus, face, Yahweh, presence, image of God.

\section{INTRODUCTION}

The ninety-five year old mother who was suffering from lung cancer had once lived with her two sons. The older son, John however, had graduated from the Indian Institute of Technology in Delhi and then began working as an IT branch manager in Silicon Valley, California. The younger son in India had been taking care of his mother in the hospital for the past five months in India, and then the diagnostic report showed that the health of the mother had been deteriorating day by day. She was informed by her doctors that she had only a few days to live. The old mother did not believe that she was going to die so soon, leaving her children orphans. She expressed to her doctors, her desire to see the face of her older son John. The doctors thinking that her final wish should be fulfilled told the younger son, who informed his older brother about the wish of his mother. He was shocked to receive the news and promised his mother that he would fulfil her last wish. At this time John was at the point of finishing a major project for work which should yield a promotion in his company. He tried to make arrangements to visit his dying mother, however, sadly, before he could reach his mother, she passed away. Her last desire to see the face of her son remained unfulfilled. The mother had wanted to feel the presence of her dear son was felt, and he was also feeling the intense absence of the presence of his dear mother, though he now held the highest position in his company. The presence of Yahweh for Moses and the Israelites in Exodus 33:1223 can be compared with this small story to demonstrate the importance of Yahweh's 
face for Israelite community. This story shows us that the face of mother could become so important in the son's life that, it could be his one's guiding principle. The importance of the presence or face of Yahweh can be seen in this scriptural text. What is the meaning of the word, 'face'in the context of the intercession of Moses? What would this 'face' have to do with the identity of Israel? Because Israelites and their identity was wavering and inconsistent as they moved to the Promised Land.

\section{ETYMOLOGY OF THE WORD 'FACE'}

The Hebrew word for 'face' is Panim which occurs over 2100 times in the OT. The English version (NAB) speaks of God's presence at 33:14 but, in Hebrew, it translates as face. Here the $\mathrm{P}$ writers consider presence to be the 'theology of the presence', of the 'face' of God, the indwelling in the midst, but the $\mathrm{E}$ writers are concerned only with the etymology. In v.13, it is as an idiom, "face to face" which suggests an honest and open relationship. In some places this word is used interchangeably as "mouth to mouth" (Num. 12:10) referring to the unique intimacy of Moses' communication with God. ${ }^{1}$ Yahweh spoke to Moses "face to face" as a friend. The usage of this term can be confusing for many readers because meaning of face is very ambivalent. One may seek to resolve this by using source criticisms' assertion that the passage is a mix of Yahwist and Elohist sources, the Elohist redactor's remote and terrible portrayal of God, surfacing in verse 20, amid the Yahwist's more anthropomorphic vision given in the surrounding verses. ${ }^{2}$ However, this strategy only serves to shed light on the theology of the persons who wrote this verse, not so much the meaning of the passage as a whole. As well, some commentaries skip over this verse entirely, or simply translate the word "face" as panim, another Hebrew word for presence. ${ }^{3}$ Yet glossing over the verse or translating the word panim still does not resolve the seeming inconsistency the verse 13 creates in the overall passage. The Hebrew word panim also means to accompany, a particular guidance for Moses, as he was going to lead the people to the land beyond his own geographical knowledge and experience.

\section{THE IDENTITY OF MOSES}

The name "Moses" stems from the Egyptian verb ' $m s y$ ' meaning 'to give birth' and appears as "Mose". He seems to have grown up with first-hand knowledge of both Canaanite and Egyptian practices. According to the nadir of Israel's fateful story, Moses epitomizes this nadir as a total orphan who has no parents, no possession, and no home. He is a helpless baby, as helpless as a fetus. The birth of Moses according to Sargon I of Mesopotamia, who lived many hundred years after Moses, indicates that Moses was born of Sargon's mother, who entrusted the baby to the mercy of the river Euphrates in a basket. ${ }^{4}$ Moses, who had an Egyptian name, married a Midianite of the Sinai region (Judg. 18: 30). His birth narrative has great historical significance A boat made up of bulrushes has a great folktale significance in the Hebrew tradition. "Bulrush" is a grass-like, hollow stem grown in marshy land. It was used by the Ethiopians as fuel (Job 41:20), and they were woven into robes (Job 41:2) because of their fragile nature. They were a symbol of weakness and vulnerability (Job 8:11-14), or representative of the lowly and insignificant. ${ }^{5}$ (Isa. 9:14). He belonged to the people who were virtually condemned to a program of genocide. ${ }^{6}$

While shepherding the flock of his father - in- law at Mount Horeb, Moses was chosen as an agent to lead the People (Exod.3:14). Yahweh revealed to Moses His name and his plan to save Israel at the event of the burning bush. What business would a shepherd have had with such a mission? In the Hebrew tradition, the word "shepherd" has many figurative features. Traditionally, most of a shepherd's work involved a routine of leading the sheep to food and water, and then returning them to the safety of the fold. They are nomadic, never having any great reputation in the ancient world. It is interesting to note that here Moses is chosen to lead his people to the land of Canaan. In the Bible, the Hebrew word nabi, which is usually 
translated as "prophet", is often used when referring to Moses, the etymology of which means 'to call'; a nabi is someone called by the deity. Therefore Moses is a spokesperson for Yahweh himself. ${ }^{7}$ Who was known as Yahweh in the history of Israelites?

The verb 'to know' occurs six times in this passage. In verses12 -13 the verb "to know" in Hebrew yada is repeated three times. "Knowing" in these verse connotes intimacy, friendship and the closeness with God with his people. ${ }^{8}$ So 'seeing God face to face' evidently means coming to know him intuitively, and thus to knowing His will. Yahweh's knowing his 'name' means that he knows Moses through and through as master-student relationship. A dialogue between Moses and God draws Moses deeper into his divine logic of encountering anthropomorphic person, a logic that Moses does not comprehend. Moses asks God in verse 16 (NRSV), "... how shall it be known that I have found favor in your sight," and how will Israel know that they are "distinct"? God simply replies that God "will do the very thing" that Moses has asked and that, again, Moses is "known" by "name" and has "found favor" in the sight of God. Again, Moses's questions seem predicated on doubt and fear, a lack of willingness to believe that God could respond with love and fidelity to human failings. By asking again for what God has already promised, Moses seeks verification, tangible confirmation of God's truthfulness. Conversely, God's use of the emphatic "will" in response to Moses, leaves no room for doubt, nor need for verification. God simply repeats the truth that Moses is "known"-using the Hebrew word yada, which connotes intimacy between loved ones-and that out of this relational intimacy flows an unconditional favor. ${ }^{9}$ In short, God has revealed to Moses that God's nature is nothing like any earthly representation or human conception. In these verses, God begins to shift the paradigm of the conversation from human skeptical empiricism to divine invisible, inter-relational trust and love. That Moses has found grace in God's eyes (v.12) means he has been elected to serve. To be elected or chosen does not mean he had a full knowledge of God.

The first indication of this shift toward a paradigm of love and trust comes with the brevity of Moses' reply, and the length of God's response, in verses 18-20. Moses says, in verse 18 simply, "show me your glory." God replies in verse 19-20 at length, saying, "I will cause all my goodness to pass in front of you, and I will proclaim my name, the Lord, in your presence. I will have mercy on whom I will have mercy, and I will have compassion on whom I will have compassion. But you cannot see my face, for no one may see me and live." By verse 18, then, Moses becomes the more silent participant. The brevity of Moses' reply and the silence that follows creates a space for God to speak, a space required for relationship to take place. Moses' being more silent also allows Moses to hear more clearly what God has to say. When Moses listens more attentively, God begins to unveil the nature of God's character, an unveiling that cannot happen has long as chatter skepticism dominates the conversation, a chatter predicated on a lack of trust that leaves little room for intimacy with God, as there is little room for God to express God's true self.

The word 'see' in v.12 is used as a motivational clause, an envelope for speech. The initial plea of Moses begins in a commanding tone, as he says to the Lord "see, you have said to me, 'Bring up this people,' but you have not let me know whom you will send with me. Again, 'You have said, "I know you by name...," then show me yours." The plea continues in the same tone as in v.13, 'Look, this nation is your people.' From the text, vv.12 and 13, the intercession of Moses seems to be singular or exclusive, and limited to himself as he says 'you have said to me...' 'You have found favor in my sight.' He is very clear and insistent that he belongs to Yahweh, and so Yahweh cannot escape responsibility. Moses had known Yahweh and his people for 40 years. He had spoken to Yahweh in the burning bush (Ex.3). He had known the name of Yahweh "I AM WHO I AM" (Ex. 3:14). He had been the leader and the mediator of the Israelites, so 
why would he ask this question? Moses' faithfulness to Yahweh and to Israel to be questioned. What does Moses want to know? What is his intense desire? The text shows that Moses was curious to know who would accompany his people. What would the future of his people be? What would be the mode of God's presence for his people? In v.13, Moses gets the answer when his plea becomes inclusive 'Look. This nation is yours.' Moses reminds Yahweh that the people whom he is leading are not his, but they are the people of Yahweh. It is Yahweh's people who are disobedient. The compassionate love and intense desire of Moses for the people melt the heart of Yahweh. It is presumed that Sinai is the real place of the divine presence, and with the departure from Sinai, the further presence of God becomes questionable for Moses and for Israel. ${ }^{10}$

\section{YAHWEH IS THE GOD OF LOVE FOR ISRAELITES}

Israel has apostatized Yahweh, yet he does not break covenant for any reason (Jud 2:1). The truth about Yahweh is that he never breaks His promise. Yahweh is still leading Israel in his Angel Ex33: 14, 19, and Jud. 2:1 for His name is in him. It is possible to note, therefore, a significant variation in the mode of revelation. At this point the Angel is not Yahweh. Yahweh has withdrawn himself from the people in order to educate Israel in the knowledge of himself. His wrath is the inevitable sign of his love. ${ }^{11}$ However, man does not appreciate this action of God. He calls it evil tidings, and is too petty to understand God's mind. Yahweh walks with Israel in parallel, but speaks only with Moses. This shows that Yahweh wants to make fuller use of Moses as an intermediary. Moses is the representative of Israel. His nature as priest, seer, and guardian of the tent fulfills all the basic functions of the later prophets and priests. The presence of God gives us the most sophisticated theology of the divine immanence in the OT of Yahweh's presence in affection and love. ${ }^{12}$ Yahweh is the god of love. The paradoxical nature of God can be seen, as E writers claim, that the deity of Israel and Mesopotamia was an awesome, unapproachable one, and displayed power through brilliance. "It is only God who does the fighting, which was recognized by both Israelites and Egyptians". ${ }^{13}$ All the violence came from God, working in and through various aspects of the non-human order. The God of Israel is a suffering sovereign, and the identity and nature of Yahweh hangs in tension, and out of this chaos life emerges, this deity Being, the god of life who is known by name (Ex.33:18). The emphasis is that 'hearing' the word is not the only vehicle of revelation, but 'seeing is believing'. Moses takes God's presence for granted.

\section{ASSURANCE OF 'PRESENCE'FOR HIS PEOPLE}

In v. 14, Yahweh answers "My presence will go with you, and I will give you rest." This connotes that Yahweh is given only to Moses (singular grace), but Moses requests for inclusive grace for the people, 'I and your people' in v. 16. Moses latches on to the necessity of Yahweh's personal presence in vv. 15 -16 as the 'sine qua non' of Israel's existence. The most significant aspect of Moses' intercession is his tenacious way of seeking to include the people with himself as objects of Yahweh's favor. 'I and your People,' repeated twice in v. 16 reveals that only Yahweh's "going with the people" makes Israel unique among nations. ${ }^{14}$ 'I and your People' corresponds to the immediate presence, not an angel or a cloud but, Yahweh himself.

Silence also uncovers the deeper rift between Moses's mode of "seeing" and "knowing," and God's mode of "seeing" and "knowing," a difference that reaches back to the visible/invisible duplicity of Israel's creation of the golden calf. The rift first becomes clear when Moses asks to "see" the "glory" of God in verse 18. The Hebrew word for "glory," kavod, pertains to some visible manifestation of God's presence. ${ }^{15}$ However, when God replies to Moses' request in verse 19, God says, "I will make...my goodness pass before you", using the Hebrew word kol-tubi which connotes an invisible nature. Moses does not, therefore, get the visible kovod that he asks 
for, but rather the invisible kol-tubi, or the "good" nature of God. ${ }^{16}$

The difference between these two words shows that, for Moses, "seeing" and "knowing" still mean visible proof, the empirical, skeptical mode of knowing. God, however, invites Moses into a mode of seeing and knowing that does not ask for proof, but for relationship, built on intimate, interior knowledge and trust, more a revealing than a showing. Therefore, when the dialogue between God and Moses moves from the paradigm of skepticism to trust, from chatter to silence, from alienation to relationship, can God lead Moses into a more intimate encounter with God's self. The deepening of their encounter comes in verse 19 when God says to Moses, "...and [I]will proclaim before you the name, 'The Lord'; and I will be gracious to whom I will be gracious, and will show mercy on whom I will show mercy." In this promise of revelation, the "I will" statements of God show that Moses [and Israel through him] will receive a revelation of God completely beyond his control, a revelation that depends solely on God's voluntary disclosure. ${ }^{17}$ This revelation, as it depends completely on God, shows Moses [and Israel] definitively that any attempt to conform God to human conception mitigates against intimacy, the intimacy with God for which the covenant stands.

'I and your People' as the repetition of Moses' interest in 'I and people' suggests that there is a genuine desire to humbly mediate on behalf of the people. However Moses' subsequent request to see "glory" in v.22 seems to overstep his boundary as mediator and enters into a perverse idolatry of his own privileged relationship with God. God's subsequent response to Moses can be seen as a refusal that protects the 'sovereign rights' of God, and challenges Moses' own conception of the privileged nature of his relationship to God. ${ }^{18}$

\section{AN ADULTEROUS DESIRE OF MOSES}

In Ex. 33:12-23, the juxtaposition between Moses' privileged relationship with God and Moses' insistence upon the holistic "nation" of Israel as the basis for relationship with God is "singled out" in its distinctiveness from God's relationship to "every other people on the earth". The mediator role of Moses' can be criticized as stemming from the desire to use theological truth to preserve power at the expense of the common people, and can serve as a helpful lens through which to examine this role.

This passage also points to the effect of God's calling Moses to this deeper intimacy: grace and vocation. God says to Moses in verses 21-23, that God will let God's "glory pass by" while Moses is protected behind a "rock" and covered with God's "hand." When God's "hand" is removed, then Moses will see the passing "back" of God, but not God's face

The Hebrew word used for the "hand" of God, kap, literally means "palm," or the most tender part of the hand, and seems to connote the "mercy" and "grace" so essential to God's nature in verses 18 and 19. ${ }^{19}$ Upon showing this mercy to Moses, God also shows Moses God's "back" which has been interpreted in some ancient commentaries as God's invitation to Moses to "follow", and by following, "becoming" more like God. ${ }^{20}$ In short, Moses does not get a one-time vision of God at the end of the passage, but much more: an invitation of evolving intimacy based on tenderness and grace, an invitation that causes Moses to both follow God, and to conform more to the image of God. Moses finds, therefore, an authentic intimacy with God and his vocation. Exodus 33; 12-23 serves as a mirror of our times; it also reflects back God's calling Moses to intimacy, authenticity and vocation upon the modern reader. This is important because we live in a so-called "postmodern" age, an age characterized by the death of grandnarratives, the constructed-self and the relativizing of all truth claims. ${ }^{21}$ Some assert that even God and religion are nothing more than constructs created by society. ${ }^{22}$ Exodus 33:12-33 serves as a kind of mirror for our times and reflectes back to us is a cautionary tale of the cost of constructing a false God, how self-made gods generate fear, skepticism, materialism, 
and ultimately threaten the life-blood of one's relationship with the one, true God. More importantly this passage shows a path out of idol worship toward an authentic intimacy with the living God, an intimacy that shatters all idols.

This might give the perspective of a modern theological liberation and a critical interpretation of privileged power imbalance. The privileged group enjoys the privileged relationship that becomes the center of an adulterous focus at the expense of the powerless. The powerful always enjoy the privileges of society. The exploitation of the power and privilege could be seen in our society.

This periscope (Ex 33:12-23) speaks volumes to the indigenous population of northern India. The land there is rich in natural resources like, the gold, bauxite, and coal. The greater part of the land in Chhattisgarh is suitable for agriculture, as it is surrounded by mountains and rivers, but the tribal population is a minority, and has no voice in the public domain. The government of Chhattisgarh has been persecuting the indigenous people and threating to displace them in the name of development. Dams are being built, and multinational companies are being set up, without the consent of the people. Many people have lost their lives protesting against the government's action, as they see that the land is being exploited for minerals by elite groups. An ecological imbalance can be detected, as very often this land has faced regular drought. The greed of the elite has brought about an existential problem to the indigenous people of northern India. The loot (robbery) of the above-mentioned natural resources has caused a great loss of life and the livelihood of the people of that district, because they are in the midst of being displaced on a massive scale without any arrangement for compensation or rehabilitation. Yahweh is a God of community who listens to the cry of weak and lowly.

\section{THE UNIQUE GIFT OF 'PRESENCE' FOR ISRAELITES}

Verses 15-16 in Exodus emphasize the importance of 'face'. The Exodus verb, ala 'to go up' to the wilderness becomes meaningless if the presence does not accompany Moses and his people. The significance of face indicates that without the appearance or presence, Moses and his people would be abandoned. The leadership of Moses would become fragile and ineffective, because it is only his presence which makes Israel distinct and unique, and so, his accompaniment is very necessary. ${ }^{23}$ Moses asks more from Yahweh than he has ever done. He is not content with Yahweh's presence; and that it is not enough. He is curious to know what kind of further favor (v.16) he and his people have received. Yahweh gives over all that was asked by Moses (v.12): In v.17, Yahweh asserts that Moses has found favor with him, and that he will be fully committed to Moses and his people in the future of Israel. The verb yada is again used, signifying that Yahweh knows Moses fully. The interesting point to note here is that Moses wanted to know Yahweh, but it is Moses who is known. The nature of Yahweh is that he always turns to humans before they turn to Him.

The parallel myth of presence or face can also be seen in sacred Hindu scripture, the Bagavad Gita, where the Lord Krishna reveals himself to Arjuna, who hesitates to fight against his kith and kins (Bg. 2:11-30). Arjuna does not want to do dharma (duty) in the absence of Lord Krishna. The Lord Krishna transforms the heart of Arjuna, who then fights the Kurukshetra war on behalf of the Pandavas, in the person of Arjuna. In the unique presence of the Lord Krishna, the insignificant tribe of the Pandavas win the battle. The goodness of the Lord Krishna overpowers the evil of society. The cowardly and unskilled warrior becomes a hero in the divine presence, and is enthroned as the king of Hastinapur (a dynasty of kings). The divine will transforms the human and, finally, the lowly and weak become stronger and heroic. 


\section{PRIVILEGES OF 'PRESENCE'}

Although Moses has received 'face', 'rest', and 'favor' he asks for something more "show me your glory" in v.18. The verb 'see' is used a third time in the text but here 'see' means God's presence in the form of his 'glory' (kavod). Yahweh's presence becomes awesome, a shrouded, magisterial presence and an over-powering light. ${ }^{24}$ Yahweh is the god of goodness (tov), the covenantal God. He is the god of promises. His powerful presence is shown in thunder, lightning, dark clouds and angels (Ex. 19:16). The presence of Yahweh is perceptible in the world in many varied ways. ${ }^{25}$ His presence fills the whole of creation "holy, holy, holy is the Lord of hosts; the whole earth is full of his glory" (Isa 6:3), and therefore it is the duty of creation, of men, women and angels to praise God.

The parallel can be seen in the Spiritual Exercises of St. Ignatius as well: "man is created to praise, reverence and serve God our Lord, and by this means to save his soul" ${ }^{26}$ The incomparable power of Yahweh is experienced by his people in history "the Lord is the everlasting God, the creator of the ends of the earth....his understanding is unsearchable" (Isa 40:28). His power is seen in different forms, in fire, cloud, storm and lightening pointing to the thunderstorm nature of God. The series of revelation connected with Noah, Moses and Abraham, who received the new relationship to Yahweh for God's people, shows the special revelation of the power of Yahweh in ancient history. ${ }^{27}$ The climax of the emphatic assurance, the protection and guidance of Yahweh, is seen in Ex. 33: 2033. Yahweh is the person of the highest possible degree, and therefore wills to be the only god for Israel. His relationship is to be "perfect" with Israel (Deut. 18:13). He is the only God of Israel from old, "Blessed be the Lord, the God of Israel from everlasting to everlasting" (Ps. 41:13). The response of Yahweh becomes the affirmation of a generous commitment to Moses and it this is precisely the proclamation of Ex. 34:5-10. This climactic proclamation and revelation lightens the burden of Moses. At last, Moses and Israel are assured of forgiveness by he who takes away rebellion and sin.

After the revelation of the name YHWH has already revealed his deep love and his grace, for those whom he has called. Then in v.19 he declares his compassion for those who need compassion. The word compassion seems to be connected with the noun for 'womb', and therefore it connotes the motherly love of the nature of YHWH. Here, God is declaring once again that his nature is love. This shows, from an incident in history, that Israel will that the grace of God flowing out of her apostasy and stiffneckedness, and traveling on as God's Face with Israel into the unknown future. The two realities are expressed as 'God is God', and 'man is Creature'. God in his absoluteness cannot be 'seen' by finite man. The paradox, seen as grace, bridges the gap, and then grace takes up and works through the sin of man. "To see the face of a king" indicates entering his presence directly, and not being seen means the refusal of an audience. In v.20 Yahweh says "you cannot see my face; for no one shall see me and live." Turning away the face, or turning the back is a sign of rejection. Hiding the face has a similar meaning. Here, it means Yahweh hides his face from one's sin, and it is a gracious act. ${ }^{28} \mathrm{~A}$ face could be cheerful or sad, even tearful, and it speaks for itself. In v.21 Yahweh wants to show his partial self "Stand up in the cleft of the rock" means more than the obvious; The Supreme Being is a mountain, the rock of ages (Ex. 6:3); the Hebrew word shaddai mean 'room to stand up'. First a man needs a 'place'. Standing up on the rock, which is itself faithful and reliable, hasthe same meaning as the word in Hebrew. It means that only by setting his feet upon a rock, can a man understand the nature of rock. Therefore only in the presence of Yahweh, can the identity of Moses and the Israelite community exist.

\section{CONCLUSION}

The face of a person unveils the character of a person; it speaks louder than words. When we look at the face of a person we try 'to know' the person, deeply and intimately. We communicate to him or her 
through our eyes. Therefore, our face symbolizes our selfhood. The face can be our best gift to another person in our relationships. Therefore, presumably the face of Yahweh is so precious and important for Moses and Israelites in order to construct their identity and intimate relationship.

The future of Israel fully depended on the face of Yahweh for accompaniment and guidance, because Israel was like Yahweh's child. Whom do we usually know in our lives? Do we associate ourselves with sinners? Do we support the people who have no voice in our society? Do we act like Moses, and ask favors for the people, and not for ourselves? Do we rise up against our racism and acknowledge those who are lowly and insignificant in our society by sharing our privileges with them?

In our socio-scientific world, technology has greatly advanced. The advent of computers, and social media like Facebook, Orkut, and Skype have increased the importance of 'facetime.' We like to talk, and connect to people face to face who are far from us. Although, the intimacy of the person, his or her presence is for just a moment, we can and do feel that person's presence.

Today, we have the sacraments, the Eucharist, the real presence of Christ in our daily lives. The Scriptures are symbols of His face, who gives us our identity of being Catholics. Our identity and existence depend on Jesus just like the identity of Moses and Israelites depended on Yahweh.

\section{Ashok Kujur}

Studied at St. the Jesuit School of Theology of St. Clara University, Berkley, California, USA.Email:akujur@gmail.com

\section{ENDNOTE}

1 John Walton \& Victor Matthews, 1997, The IVP Bible Background Commentary, Intervarsity Press, Illinois, 136.
2 Eerdmans Dictionary of the Bible (Grand Rapids MI: William B. Eardmans Publishing, 2000, 402403.

3 Hyatt, Philip. 1962, New Century Bible Commentary on Exodus, TN Vanderbilt University Press, Nashville, 262.

4 Brevard S. Childs, 1974, The Book of Exodus, A Critical Theological Commentary, The Westminster, Philadelphia, 583.

5 Brevard, 583.

6 George A.F. Knight, 1976, Theology as Narration, A commentary on the Book of Exodus, New York: William B. Eerdmans Publishing Company, 58.

7 Michael D. Coogan, 2006, The Old Testament, A Historical and Literary Introduction to the Hebrew Scriptures, Oxford University Press, New York, 300

8 Nuam M. Sarna 2000, Commentary, Exodus: The JPS Torah Commentary with Hebrew Text (The Jewish Publication Society, Philadelphia, 214.

9 Sarna, 203.

10 Martin Noth, 1962, Exodus, A Commentary, The Westminster, Philadelphia, 257.

11 George A.F. Knight, 1976, Theology as Narration, A commentary on the Book of Exodus, William B. Eerdmans Publishing Company, New York, 197.

12 George A.F. Knight, 1976, Theology as Narration, A commentary on the Book of Exodus, William B. Eerdmans Publishing Company, New York, 195.

13 Terence E. Fretheim, 1991, Interpretation, A Bible Contemporary for Teaching and Preaching, John Knox Press, Louisville 19, 298.

14 Dale Ralph Davis, 1982, Rebellion, Presence and Covenant, A study in Exodus 32 -3471, 87,

15 Sarna, 212.

16 Hamilton, William. Exodus: An Exegetical Commentary, (Grand Rapids: Barker Publishing, 2011), 570.

17 Sarna, 214.

18 Davies, G. Henton, 1967, Exodus, Introduction and Commentary, Gatesheah, Northumberland Press, Great Britain, 242

19 Anchor Bible Commentary, 608.

20 Stern, Josef., 2013, The Matter and Form of Maimonides' Guide MA Harvard College Fellows Press, Boston, 270.

21 Giddens, Anthony, 1991, Modernity and SelfIdentity, CA Stanford University Press, Stanford.

22 Durkheim, Emile, 1995, The Elementary Forms of Religion, Trans. Karen Fields NY Free Press, New York:

23 Lawrence Boad 1984, Reading The Old Testament, An Introduction, Paulist Press, New York, 103.

24 Dale Ralph Davis, 1982, Rebellion, Presence and Covenant, A study in Exodus 32 -34, 77.

25 Brevard, 35. 
26 Louis J. Puhl, S.J. 2000, The Spiritual Exercises of St. Ignatius, Vintage Spiritual Classics, New York, 12.

27 Gerhard Von Rad, The Old Testament Theology, Theology of Israel's Historical Translation (vol.1 1986), 56.

28 Joel F. Drinkard, Jr. The Anchor Bible Dictionary (vol.-2, 1992), 744.

\section{BIBLIOGRAPHY:}

Boad, Lawrence, 1984, Reading The Old Testament, An Introduction. Paulist Press, New York.

Childs S. Brevard, 1974, The Book of Exodus:A Critical Theological Commentary. The Westminster Press, Philadelphia.

Coogan, Micahel D. 2006, The Old Testament:A Historical and Literary Introduction to the Hebrew Scriptures. Oxford University Press, New York.

Drinkard, Joel F., Jr. 1992, The Anchor Bible Dictionary vol.-2.

Fretheim, Terence E. 1991, Interpretation: A Bible Contemporary for Teaching and Preaching. John Knox Press, Louisville.

George, A.F. Knight, 1976, Theology as Narration: A commentary on the Book of Exodus. William B. Eerdmans Publishing Company, New York.
Henton, Davies, G., 1967, Exodus: Introduction and Commentary. Gatesheah, Norhthumberland Press, Great Britain.

Noth, Martin, 1962, Exodus: A Commentary. The Westminster Press, Philadelphia.

Philip, Hyatt, 1962, New Century Bible Commentary on Exodus. Vanderbilt University Press, Nashville, TN.

Puhl, Louis J., 2000, The Spiritual Exercises of St. Ignatius. Vintage Spiritual Classics, New York.

Rad, Gerhard Von, The Old Testament Theology, Theology of Israel's Historical Translation, vol.1 1986.

Ralph, Dale Davis, 1982, Rebellion, Presence and Covenant, A study in Exodus 32 -34, WTJ 44.

Sarna, Nuam M. Commentary, 2000, Exodus: The JPS Torah Commentary with Hebrew Text. The Jewish Publication Society, Philadelphia.

Walton, John \& VictorMatthews, 1997, The IVP Bible Background Commentary, Intervarsity Press, Illinois.

William, Hamilton, 2011, Exodus, An Exegetical Commentary, Barker Publishing, Grand Rapids. 